\title{
Influence of UV-B Pretreatments on Kinetics of Convective Hot Air Drying and Physical Parameters of Mushrooms (Agaricus bisporus)
}

\author{
Arman Forouzanfar ${ }^{1}$, Mohammad Hojjati ${ }^{1, * \mathbb{C}}$, Mohammad Noshad ${ }^{1}$ \\ and Antoni Jacek Szumny ${ }^{2}$ (D) \\ 1 Department of Food Science and Technology, Agricultural Sciences and Natural Resources University \\ of Khuzestan, Ahvaz 63417-73637, Iran; armanforouzanfar@gmail.com (A.F.); noshad@asnrukh.ac.ir (M.N.) \\ 2 Department of Food Chemistry, Wrocław University of Environmental and Life Sciences, Norwida 25, \\ 50-375 Wrocław, Poland; antoni.szumny@upwr.edu.pl \\ * Correspondence: hojjati@asnrukh.ac.ir; Tel.: +98-612-3652-4341
}

Received: 22 July 2020; Accepted: 16 August 2020; Published: 20 August 2020

check for updates

\begin{abstract}
The present study aimed to investigate the effects of ultraviolet-B (UV-B) pretreatments on selected physical properties (shrinkage, rehydration, color, texture) and drying kinetics and to model the drying kinetics of hot air dried mushrooms using several mathematical models, such as the Henderson-Pabis, logarithmic, two-term, Verma, Wang and Singh, Midilli, and modified Henderson-Pabis models. Results showed that the use of UV-B pretreatment before mushroom drying reduced shrinkage, color changes, firmness, and drying time and increased rehydration and the effective moisture diffusion coefficient. The amount of activation energy increased from $16.55 \pm 1.3 \mathrm{~kJ} / \mathrm{mol}$ (control sample) to $18.27 \pm 2.2 \mathrm{~kJ} / \mathrm{mol}$ (UV-B treated samples for $30 \mathrm{~min}$ ), $19.72 \pm 1.4 \mathrm{~kJ} / \mathrm{mol}$ (UV-B treated samples for $60 \mathrm{~min}$ ), and $21.9 \pm 1.9 \mathrm{~kJ} / \mathrm{mol}$ (UV-B treated samples for $90 \mathrm{~min})$. However, increasing the drying temperature increased the shrinkage and firmness of samples. The modified Henderson-Pabis model with the highest correlation coefficient $\left(R^{2}\right)$ and lowest root mean square error (RMSE) and chi-square $\left(\chi^{2}\right)$ showed the best fit for every drying curve, proving to be an excellent tool for the prediction of drying time.
\end{abstract}

Keywords: hot air assisted drying; UV light; modeling technique; mushroom; activation energy

\section{Introduction}

Champignon mushrooms (Agaricus bisporus (J.E. Lange) Imbach), also known as button mushrooms, are agricultural products that usually deteriorate in quality after harvest due to reduced moisture, shrinkage, discoloration, and softening of their texture. Therefore, various methods are used to store button mushrooms, the most common of which is drying [1,2]. Hot air drying is by far the most common method of drying, which includes simultaneous heat and mass transfer. In traditional drying methods, a high temperature or a long duration is used, which consumes a high amount of energy and is also time-consuming, leading to undesirable physical and chemical changes, such as changes in color, smell, and taste; it also reduces nutrients and causes shrinkage in the product. Thus, food quality can be maintained in a desirable manner by using other methods of drying or using pretreatment $[3,4]$. To date, many pretreatment methods have been used to shorten drying time and thus improve the quality of mushrooms, some of which include button mushroom immersion in osmotic solutions such as $7 \%$ $w / w$ of sodium chloride [5], ultrasonic pretreatment [6], and infrared pretreatment [7]. Selecting the appropriate drying methods can improve the quality characteristics of dried fruits and reduce time and energy consumption during the drying process [3]. Today, ultraviolet light (UV) treatment is mainly 
used to extend the shelf life of fruit and vegetables by reducing microbiota growth as well as enhancing their nutritional quality by positively affecting phytochemical values [8-10]. In recent years, the use of UV has been considered as a pretreatment in the drying process [11]. Generally, the UV radiation spectrum is divided into three regions, UV-C (wavelength 220 to $280 \mathrm{~nm}$ ), UV-B (wavelength 280 to $320 \mathrm{~nm}$ ), and UV-A (wavelength 320 to $400 \mathrm{~nm}$ ). UV-B is the most energetic type of solar radiation that reaches the Earth's surface [12,13]. Braga et al. (2018) examined the use of UV lamps as a pretreatment in the drying process of mangoes and showed that UV pretreatment reduced the moisture content of the samples and increased the amounts of bioavailable vitamins in the samples. The high energy of the pulsed light treatment may have broken the bonds of the vitamins, changing them to their free and bioavailable form, thus resulting in a slightly higher content of vitamins in the treated dried product [11]. One of the most important aspects of any drying technology, especially for industrial processes, is the modeling of the drying process. The purpose of modeling is to choose the most appropriate method of drying, as well as to choose suitable operating conditions for the product. Knowledge of drying behavior is an important factor in designing, simulating, and optimizing the drying process $[14,15]$. Zhang et al. (2019) examined the effect of ultrasound as a pretreatment on the drying kinetics of button mushrooms. This study showed that the logarithmic model is the most suitable model for describing the drying process of mushrooms [16]. Since limited studies have been conducted on the use of UV-B pretreatment in mushroom drying, the aim of this study was to investigate the effect of UV-B pretreatment on drying kinetics and selected physical properties of dried button mushrooms by the hot air method.

\section{Materials and Methods}

\subsection{Materials}

Agaricus bisporus (button mushroom) specimens with initial humidity of $90 \%$ (wet weight bases) were purchased from Jolgeh dez Agricultural Company (Dezful, Iran). UV-B lamps (TL 20 W/12 RS SLV/25, Philips, Hamburg, Germany) were used for the UV-B pretreatment, which were placed in a small room measuring $15 \times 35 \times 65 \mathrm{~cm}$ and at a distance of $7 \mathrm{~cm}$ from the samples.

\subsection{Drying}

In order to investigate the effect of UV-B pretreatment time (30, 60, and $90 \mathrm{~min})$ and the drying temperature $\left(40,50\right.$, and $\left.60^{\circ} \mathrm{C}\right)$ on the kinetics and qualitative characteristics of the control samples (no pretreatment) and samples with pretreatment of UV-B, around $50 \mathrm{~g}$ of each of the samples was placed in a cabinet dryer (Model X1, Behdooneh Co., Babolsar, Iran) equipped with an air controller and digital thermometer and hygrometer at a speed of $1.5 \mathrm{~m} / \mathrm{s}$ until their moisture content reached $15 \%$. The water activity (Novasina ${ }^{\mathrm{TM}} \mathrm{ms1}$-aw, Novasina, Pfaffikon, Switzerland) of all dried samples was in the range of $0.61-0.67$. It should be noted that the control samples were specified at 40,50, and $60{ }^{\circ} \mathrm{C}$, in the form of $\mathrm{C} 40, \mathrm{C} 50$, and C60, and the samples treated with UV-B for 30, 60, and $90 \mathrm{~min}$ and at 40,50 , and $60^{\circ} \mathrm{C}$ were specified in the form of U30-40, U30-50, U30-60, U60-40, U60-50, U60-60, U90-40, U90-50, and U90-60.

\subsection{Shrinkage}

The shrinkage of samples was investigated by measuring the sample volume change. Volume was estimated gravimetrically by displacement of toluene in a pycnometer, based on the method described by Yan et al. [14]. Distilled water was used to calibrate a flask. The volume of the flask was evaluated to be $48.91 \mathrm{~mL}$. The density of toluene, which was determined by weighing the flask while full of 
toluene, was found to be $874 \mathrm{~kg} / \mathrm{m}^{3}$. The samples were weighed and then transferred into a flask filled with toluene. The volume of samples was calculated by the following Equation (1):

$$
V=V_{f}-\frac{M_{t+s}-M_{f}-M}{P_{s}}
$$

where $V_{f}$ is the volume of the flask, $M_{t+s}$ is the weight of the flask plus the sample and the solvent, $M_{f}$ is the weight of the flask, and $P_{s}$ is the density of toluene. Thus, the volume of the samples was measured before and after drying and the shrinkage of the samples was calculated using the Equation (2) [17]:

$$
\% S h=\left(1-\frac{V}{V_{0}}\right) \times 100
$$

where $V_{0}$ is initial sample volume, $V$ is dried sample volume, and $S h$ is Shrinkage (\%).

\subsection{Rehydration}

Rehydration was performed using the Szadzińska (2018) method. For this purpose, the dried samples were immersed in distilled water at $100{ }^{\circ} \mathrm{C}(1: 50(w / w))$ for $5 \mathrm{~min}$. Then, the rate of water reabsorption by the samples was calculated using the following Equation (3) [18]:

$$
\text { Rehydration }=\frac{M_{1}-M_{0}}{M_{0}}
$$

where $M_{0}$ and $M_{1}$ are sample weights (g) before and after the rehydration process, respectively.

\subsection{Color}

The color of the samples was measured with a colorimeter (CR-400, Konica Minolta, Osaka, Japan) using an illuminant D65 and $10^{\circ}$ observer angle. The device was calibrated according to the manufacturer's instructions [19] before each measurement period using the white calibration standard tile $\left(\mathrm{L}^{*}=96.9, \mathrm{a}^{*}=-0.04, \mathrm{~b}^{*}=1.84\right)$. Color data are provided as CIE $L^{*} a^{*} b^{*}$ coordinates, which define color in a three-dimensional space. $L^{*}$ expresses the lightness, taking values within the range of 0 (black)-100 (white). $a^{*}$ and $b^{*}$ represent the green-red and the blue-yellow colors, respectively. $a *$ uses positive values for reddish colors and negative values for the greenish ones, whereas $b$ * uses positive values for yellowish colors and negative values for bluish ones [20]. All color analyses were run in ten replicates $(n=10)$. The total color changes $(\Delta \mathrm{E})$ were calculated using the following Equation (4) [21]:

$$
\Delta E=\sqrt{\Delta L^{2}+\Delta a^{2}+\Delta b^{2}}
$$

where $\Delta L\left(L_{A}-L_{0}\right), \Delta a\left(a_{A}-a_{0}\right)$, and $\Delta b\left(b_{A}-b_{0}\right)$ indicate the mathematical differences measured in $L^{*}, a^{*}$, and $b^{*}$ values of samples after $(A)$ and before $(0)$ drying.

\subsection{Texture}

The texture characteristics of the samples were examined after drying using a Texture Analyzer (TA.XT. PLUS, Stable Micro Systems, Surrey, UK). In order to determine the firmness of the samples, a penetration test was performed using a $6 \mathrm{~mm}$ probe with a speed of $50 \mathrm{~mm} / \mathrm{min}$ and a penetration depth of $2 \mathrm{~mm}$. The force (in newtons) required for penetration by the probe was used to measure the firmness of the texture [3]. 


\subsection{Mathematical Modeling}

A moisture ratio was used during the drying process for modeling the drying kinetics. The moisture ratio was calculated according to the initial moisture, equilibrium moisture, and moisture of the samples at each drying time with the Equation (5) [22]:

$$
M R=\frac{M_{t}-M_{e}}{M_{0}-M_{e}}
$$

In the above equation, $M R$ is the moisture ratio, $M_{t}$ is moisture uptake at a given time, $M_{e}$ is the equilibrium moisture, and $M_{0}$ is the initial moisture of the sample. Drying curves were fitted to different drying models, as shown in Table 1.

Table 1. Mathematical models given by various authors for the drying curves.

\begin{tabular}{ccc}
\hline Model Name & Model Equation & References \\
\hline Henderson-Pabis & $M R=\mathrm{a} \exp (-\mathrm{k} \mathrm{t})$ & {$[23]$} \\
Logarithmic & $M R=\mathrm{a} \exp (-\mathrm{k} \mathrm{t})+\mathrm{c}$ & {$[24]$} \\
Two-term & $M R=\mathrm{a} \exp \left(-\mathrm{k}_{0} \mathrm{t}\right)+\mathrm{b} \exp \left(-\mathrm{k}_{1} \mathrm{t}\right)$ & {$[25]$} \\
Verma & $M R=\mathrm{a} \exp (-\mathrm{k} \mathrm{t})+(1-\mathrm{a}) \exp (-\mathrm{g} \mathrm{t})$ & {$[24]$} \\
Wang and Singh & $M R=1+\mathrm{at}+\mathrm{b} \mathrm{t}^{2}$ & {$[24]$} \\
Midilli et al. & $M R=\mathrm{a} \exp \left(-\mathrm{k} \mathrm{t}^{n}\right)+\mathrm{b} \mathrm{t}$ & {$[25]$} \\
Modified Henderson-Pabis & $M R=\mathrm{a} \exp (-\mathrm{k} \mathrm{t})+\mathrm{b} \exp (-\mathrm{g} \mathrm{t})+\mathrm{c} \exp (-\mathrm{h} \mathrm{t})$ & {$[23]$} \\
\hline
\end{tabular}

A data fit on drying models was performed using MATLAB software (R2016a, The Math Works Inc., Natick, MA, USA). The correlation coefficient $\left(R^{2}\right)$, root mean square error (RMSE), and chi-square $\left(\chi^{2}\right)$ were used to select the best model [26] with the following Equations (6)-(8):

$$
\begin{gathered}
R^{2}=\frac{\sum\left(O_{\text {pre }}-\sigma\right)^{2}}{\sum\left(O_{\text {exp }}-\sigma\right)^{2}} \\
R M S E=\sqrt{\frac{\sum\left(O_{\text {exp }}-O_{p r e}\right)^{2}}{k}} \\
x^{2}=\sum \frac{\left(O_{\text {pre }}-O_{\text {exp }}\right)^{2}}{k-m}
\end{gathered}
$$

In that $k$ is in the number of experimental data, $m$ is the number of model parameters, $O_{\exp }$ is the experimental value of moisture content, $O_{\text {pre }}$ is the prediction value of moisture content, and $\sigma$ is the mean value of moisture content.

\subsection{Determination of Effective Moisture Diffusion Coefficient}

The Fick equation was used in order to evaluate the moisture diffusion coefficient using the following Equation (9) [27]:

$$
M R=\frac{8}{\pi^{2}} \sum_{n-1}^{\infty} \frac{1}{(2 n+1)^{2}} \exp \left(-\frac{(2 n+1)^{2} \pi^{2} D_{e f f} t}{4 L_{0}^{2}}\right)
$$

where $M_{0}$ is the moisture content in $\mathrm{kg}$ water $/ \mathrm{kg}$ dry matter at the beginning of the drying. $M_{t}$ is moisture content in $\mathrm{kg}$ water $/ \mathrm{kg}$ dry matter at time $t . M_{e}$ is moisture content in $\mathrm{kg}$ water $/ \mathrm{kg}$ dry matter when equilibrium was reached. $D_{\text {eff }}$ is diffusion coefficient $\left(\mathrm{m}^{2} / \mathrm{s}\right) ; t$ is time (s), and $L_{0}$ is half the thickness $(\mathrm{m}) . n$ is the number of terms taken into consideration. 


\subsection{Activation Energy}

The Arrhenius equation was used to calculate the activation energy using the Equation (10) [23]:

$$
D_{\text {eff }}=D_{0} \exp \left(\frac{-E_{a}}{R T}\right)
$$

where $E_{a}$ is energy of activation $(\mathrm{KJ} / \mathrm{mol}), R$ is the universal gas constant $(8.3 \mathrm{KJ} / \mathrm{mol} \mathrm{K}), T$ is absolute air temperature $(\mathrm{K})$, and $D_{0}$ is the exponential factor of the Arrhenius equation $\left(\mathrm{m}^{2} / \mathrm{s}\right)$.

\subsection{Statistical Analysis}

Experiments were evaluated based on a completely randomized design with three replications. The Duncan multiple range test was utilized to compare the means and investigate the effects of treatments. During all stages of statistical analysis, SPSS 19 was used to analyze the data. For all statistical analyses, significance was established at the $5 \%$ level.

\section{Results and Discussion}

\subsection{Shrinkage}

As observed in Table 2, using UV-B pretreatment before drying the mushrooms had a significant effect on reducing the shrinkage of the samples, and increasing the drying temperature increased the amount of shrinkage in the samples (Table 2). The highest shrinkage was related to the C60 sample and the lowest shrinkage was related to the U90-40 sample (Figure 1). Some of the most important factors affecting the rate of shrinkage of the samples are the temperature and the intensity of drying (process time) [28]. The use of UV-B pretreatment reduced the drying time and thus reduced the shrinkage in the samples. However, by increasing the temperature in the hot air method, the heat transferred to the inside of the product increases and the amount of moisture in the product decreases, and, as a result, shrinkage also increases due to the tension stresses that occur in the cellular structure [29]. Our findings were consistent with those of other researchers [28-31].

Table 2. Effect of ultraviolet-B (UV-B) pretreatments on selected physical properties (shrinkage, rehydration, color, texture) of hot air dried mushrooms.

\begin{tabular}{ccccc}
\hline Sample & Shrinkage (\%) & Firmness $(\boldsymbol{N})$ & $\Delta E$ & Rehydration \\
\hline C40 & $63.81 \pm 0.10^{\mathrm{ab}}$ & $2.22 \pm 0.01^{\mathrm{cde}}$ & $14.9 \pm 1.43^{\mathrm{bc}}$ & $2.08 \pm 0.05^{\mathrm{bc}}$ \\
$\mathrm{C} 50$ & $64.40 \pm 0.21^{\mathrm{ab}}$ & $2.25 \pm 0.04^{\mathrm{ab}}$ & $16.3 \pm 2.14^{\mathrm{ab}}$ & $1.78 \pm 0.06^{\mathrm{cd}}$ \\
$\mathrm{C} 60$ & $64.52 \pm 0.12^{\mathrm{a}}$ & $2.30 \pm 0.04^{\mathrm{a}}$ & $18.9 \pm 2.11^{\mathrm{a}}$ & $1.58 \pm 0.04^{\mathrm{d}}$ \\
$\mathrm{U} 30-40$ & $62.93 \pm 0.12^{\mathrm{abc}}$ & $2.23 \pm 0.01^{\mathrm{bcd}}$ & $11.98 \pm 1.10^{\mathrm{de}}$ & $2.28 \pm 0.06^{\mathrm{b}}$ \\
$\mathrm{U} 30-50$ & $63.43 \pm 0.23^{\mathrm{abc}}$ & $2.24 \pm 0.02^{\mathrm{bc}}$ & $14.07 \pm 1.81^{\mathrm{bcd}}$ & $1.85 \pm 0.02^{\mathrm{cd}}$ \\
$\mathrm{U} 30-60$ & $63.77 \pm 0.22^{\mathrm{ab}}$ & $2.27 \pm 0.02^{\mathrm{ab}}$ & $15.01 \pm 1.43^{\mathrm{b}}$ & $1.63 \pm 0.01^{\mathrm{d}}$ \\
$\mathrm{U} 60-40$ & $61.94 \pm 0.33^{\mathrm{bcd}}$ & $2.18 \pm 0.01^{\mathrm{def}}$ & $9.47 \pm 1.72^{\mathrm{de}}$ & $2.38 \pm 0.02^{\mathrm{b}}$ \\
$\mathrm{U} 60-50$ & $62.92 \pm 0.22^{\mathrm{abc}}$ & $2.23 \pm 0.0 .3^{\mathrm{bc}}$ & $9.85 \pm 1.17^{\mathrm{ef}}$ & $2.10 \pm 0.04^{\mathrm{bc}}$ \\
$\mathrm{U} 60-60$ & $62.87 \pm 0.25^{\mathrm{abc}}$ & $2.26 \pm 0.01^{\mathrm{ab}}$ & $12.18 \pm 1.36^{\mathrm{cde}}$ & $2.07 \pm 0.09^{\mathrm{bc}}$ \\
$\mathrm{U} 90-40$ & $56.26 \pm 0.13^{\mathrm{e}}$ & $2.16 \pm 0.02^{\mathrm{f}}$ & $6.78 \pm 1.34^{\mathrm{g}}$ & $3.08 \pm 0.07^{\mathrm{a}}$ \\
$\mathrm{U} 90-50$ & $59.10 \pm 0.21^{\mathrm{ed}}$ & $2.15 \pm 0.01^{\mathrm{f}}$ & $7.40 \pm 1.73^{\mathrm{fg}}$ & $2.46 \pm 0.06^{\mathrm{b}}$ \\
$\mathrm{U} 90-60$ & $60.8 \pm 0.1^{\mathrm{cd}}$ & $2.17 \pm 0.01^{\text {ef }}$ & $7.49 \pm 1.52^{\mathrm{fg}}$ & $2.31 \pm 0.10^{\mathrm{b}}$ \\
\hline
\end{tabular}

The same letters in columns means no statistical differences were found between samples $(p<0.05)$ according to Duncan's multiple range test.

\subsection{Texture}

According to the obtained data from Table 2, the use of UV-B pretreatment reduces the fracture force of the pretreated samples compared to the control samples. The probable reason for this occurrence is that applying pretreatment reduces the drying time and destroys the cell walls in the sample texture, which, as a result, softens the texture. Although this hypothesis has not yet been clearly proven, 
it can be proven by impedance measurement of the tissue. In addition, with increasing temperature, the fracture force of the cell walls increased. The highest fracture force of the cell walls in control and pretreated samples was observed at $60^{\circ} \mathrm{C}$, and the lowest fracture force rate was observed at $40^{\circ} \mathrm{C}$ (Table 2). The reason for this is that, with increasing drying temperature, the moisture removal rate from the samples increases and the surface hardness of the samples increases. The phenomenon of surface hardening of samples increases with the increasing temperature and results in the hardening of the surface of the dried samples, which, in turn, increases the fracture force of the samples [30].

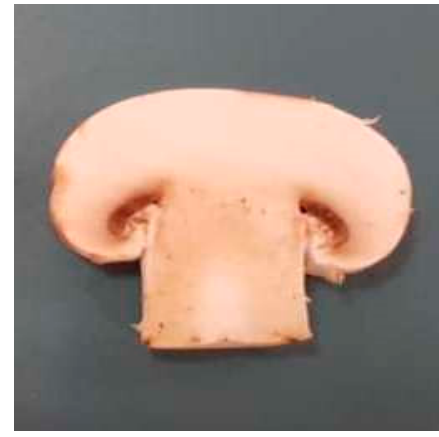

(A)

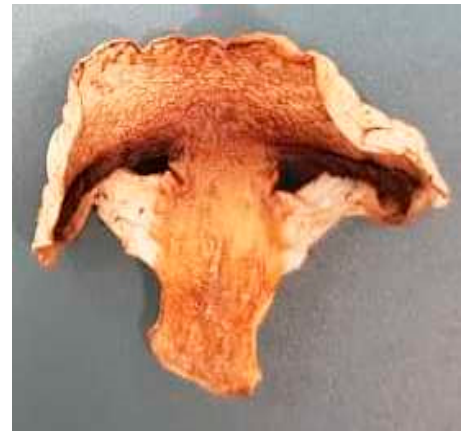

(B)

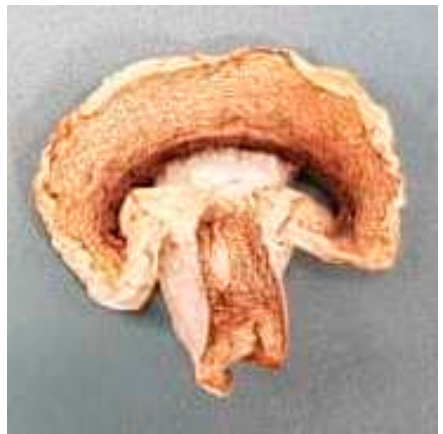

(C)

Figure 1. Image of a raw mushroom before drying (A); a mushroom dried without pretreatment at $60^{\circ} \mathrm{C}(\mathbf{B})$, and a mushroom pretreated with UV-B (90 min) and dried at $40{ }^{\circ} \mathrm{C}(\mathrm{C})$.

\subsection{Color}

The results showed that the highest rate of color change during the drying process was related to the control samples (no pretreatment process). After applying UV-B pretreatment, the color change of the samples was reduced when compared to the control samples (Table 2). One of the reasons for the decrease in the color change of the pretreated samples compared to the control samples is that the application of the pretreatment reduced the drying time, which, in turn, caused the product to be in contact with hot air for a shorter time, resulting in reduced enzymatic and non-enzymatic browning reactions in the samples [30]. However, as the temperature increased, the color change of the samples also increased due to the increased decomposition of pigments and the enzymatic and non-enzymatic browning reactions that increase with increasing temperature [32].

\subsection{Rehydration}

Rehydration can be a criterion for assessing the damage caused by drying or pre-drying treatments. The rate of rehydration is significantly affected by the texture characteristics of the product and the low rehydration rate indicates the collapse of the internal structure of the sample [33]. Based on the obtained findings, using UV-B pretreatment increased the rate of water rehydration by the samples (Table 2). Since UV-B waves are absorbed only by the surface of the samples, there is a probability of an increase in the diameter of the pores in the cell wall, without side effects on the capillary tubes inside the samples. In control samples (without UV-B pretreatment), the lack of surface pores creates more pressure on the capillary tubes and, as a result, the rate of rehydration by the samples is reduced [34]. However, as the temperature increased, the rate of rehydration by the samples decreased, which is probably due to the destruction of the orifice and capillary pores in the structure of the product (Table 2) [4]. The use of scanning electron microscopy is recommended in order to further investigate the effect of the process on the pore size. In general, the data from Table 2 indicate that the use of UV-B pretreatment reduced shrinkage, color changes, and firmness and, on the other hand, increased the rehydration of the dried samples, while the U90-40 treatment had the greatest effect on these characteristics. 


\subsection{Effects of Pretreatment and Air Temperature on Moisture Ratio}

As depicted in Figure 2 (the general trend was similar for all three temperatures), the use of UV-B pretreatment before drying reduced the drying time of the mushroom. Applying UV-B pretreatment increases the diameter of the pores in the cell wall without exerting side effects on the capillary tubes inside the sample. As a result, the moisture removal of the product increased, thus decreasing the drying time of the mushrooms. In the control sample, due to the removal of moisture from the surface of the product and the phenomenon of shrinkage, the capillary tubes on the surface of the product were almost blocked. This blockage is intensified due to water outflow, which, in turn, reduces the moisture removal of the product and increases the drying time of the samples [34]. In addition, the drying time of the mushrooms decreased as the temperature increased (Figure 3). As the temperature rises, the destruction of the membrane layers also increases and the texture of the product is further damaged, which is followed by the removal of more moisture. In addition, the increase in temperature, along with the increase in the molecular movement, causes more water molecules to come out of the product, which reduces the drying time [25].

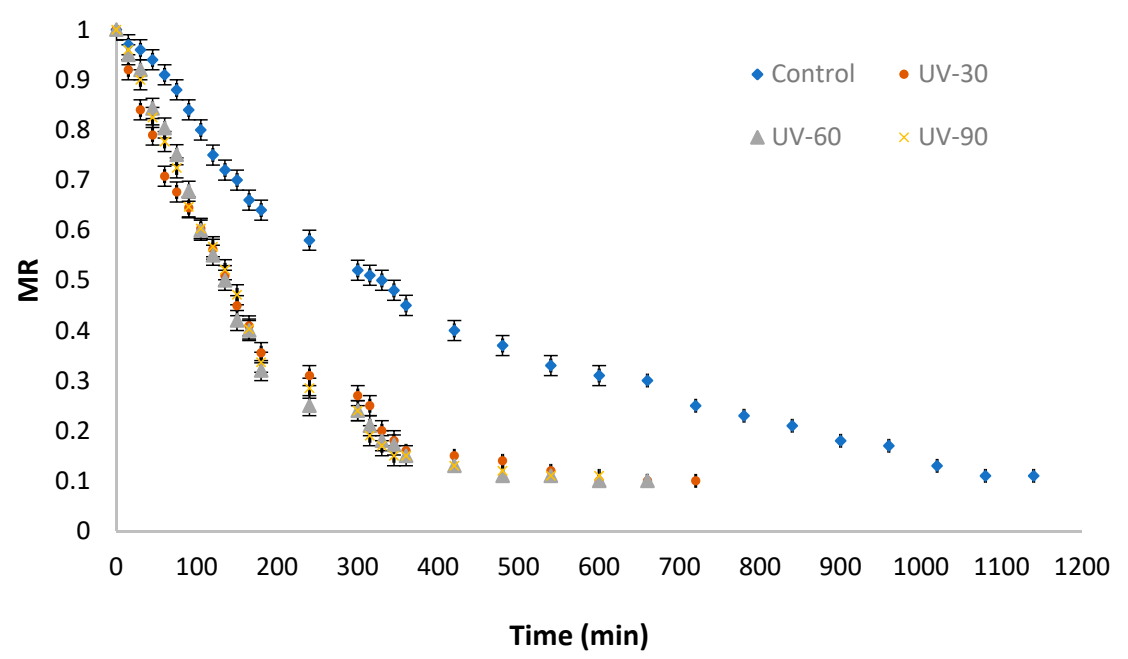

Figure 2. Effect of UV-B pretreatment on moisture ratio $(\mathrm{MR}) \pm \mathrm{SD}$ with drying time of samples at $50{ }^{\circ} \mathrm{C}$ (the bars smaller than the point on the graph are not shown).

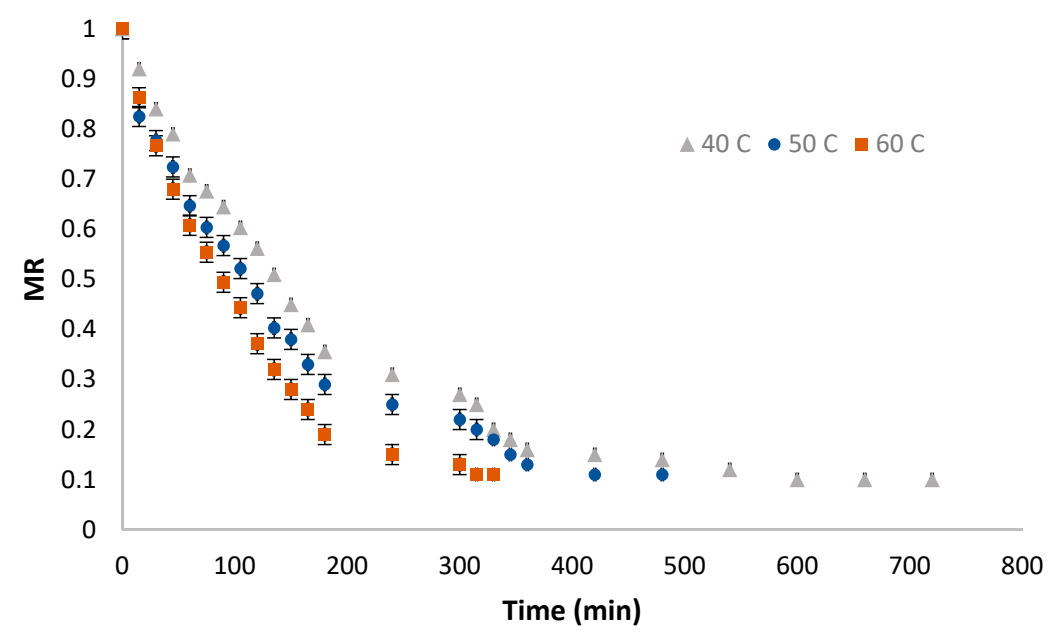

Figure 3. The effect of temperature on moisture ratio $(M R) \pm S D$ with drying time of treated samples exposed to UV-B for $60 \mathrm{~min}$ (the bars smaller than the point on the graph are not shown). 


\subsection{Modeling of Drying Curves}

In order to model the drying kinetics of treated and control mushrooms, different models were compared in terms of $\mathrm{R}^{2}$, RMSE, and $\chi^{2}$. Ultimately, the modified Henderson-Pabis model had the highest $\mathrm{R}^{2}$ and the lowest RMSE and $\chi^{2}$ and was therefore selected as the best model. Thus, the modified Henderson-Pabis model had the best fit with the experimental data at all drying temperatures. The statistical results of this model are presented in Table S1 as a supplementary file.

\subsection{Determination of Effective Diffusivities}

The values of the effective diffusion coefficient during drying and energy activation of the samples can be seen in Table 3. There was an increase in the effective diffusion coefficient of moisture with increasing temperature and application of UV-B pretreatment (Table 3). The effective diffusion coefficient of moisture for the control sample at $40-60^{\circ} \mathrm{C}$ was $2.43 \times 10^{-9}$ to $3.2 \times 10^{-9}\left(\mathrm{~mm}^{2} / \mathrm{s}\right)$. As the temperature increases, the molecular motion and surface tension of the water also increases, which leads to an increase in the effective diffusion coefficient of moisture in the samples [35]. In addition, the use of UV-B pretreatment reduces the blockage and shrinkage of the cell wall due to the increase in the diameter of the cellular orifice, and this too increases the effective diffusion coefficient of moisture [34].

Table 3. Values of effective diffusivity obtained for mushrooms under different drying conditions.

\begin{tabular}{ccccc}
\hline \multirow{2}{*}{ Temperature $\left({ }^{\circ} \mathbf{C}\right)$} & \multicolumn{4}{c}{ Effective Diffusivity $\left(\mathbf{m}^{2} / \mathbf{s}\right)$} \\
\cline { 2 - 5 } & Control & U30 & U60 & U90 \\
\hline 40 & $2.43 \times 10^{-9}$ & $2.56 \times 10^{-9}$ & $2.71 \times 10^{-9}$ & $2.78 \times 10^{-9}$ \\
50 & $2.74 \times 10^{-9}$ & $2.76 \times 10^{-9}$ & $2.87 \times 10^{-9}$ & $2.92 \times 10^{-9}$ \\
60 & $3.2 \times 10^{-9}$ & $3.25 \times 10^{-9}$ & $3.32 \times 10^{-9}$ & $3.39 \times 10^{-9}$ \\
\hline
\end{tabular}

\subsection{Determination of Activation Energy}

It is essential to have knowledge of activation energy as a tool for designing and modeling mass transfer in food processes such as drying. Activation energy indicates temperature sensitivity and emission capability [24]. Based on the obtained findings, the amount of activation energy increased with the application of UV-B pretreatment from $16.55 \pm 1.3$ (control sample) to $18.27 \pm 2.2 \mathrm{~kJ} / \mathrm{mol}$ (UV-B treated samples for $30 \mathrm{~min}$ ), $19.72 \pm 1.4 \mathrm{~kJ} / \mathrm{mol}$ (UV-B treated samples for $60 \mathrm{~min}$ ), and $21.9 \pm 1.9 \mathrm{~kJ} / \mathrm{mol}$ (UV-B treated samples for $90 \mathrm{~min}$ ). The probable reason for this is that the use of UV-B pretreatment has increased the diameter of the cellular orifice in the sample texture, as well as increasing the effective diffusion coefficient of moisture, leading to the increase in the activation energy [36].

\section{Conclusions}

The effect of UV-B pretreatments on drying rate and physical properties (shrinkage, rehydration, color, texture) were evaluated. In the falling-rate period of the drying of mushrooms, the diffusion mechanism controlled the moisture movement. UV-B pretreatments and drying air temperature affected the drying rate and time. The drying rate increased with increasing UV-B pretreatment and drying air temperature. The modified Henderson-Pabis model can be used to model the kinetics of drying the control and treated mushrooms. These findings indicate that the shrinkage, color change, and firmness of the product, which are considered to be undesirable quality parameters in dried mushrooms, are reduced by using the UV-B pretreatment before drying. Therefore, the use of UV-B is recommended as a suitable pretreatment in drying mushrooms. However, further tests such as sensory evaluation are suggested for future studies in order to make a final decision as to the effectiveness of UV-B pretreatments in the drying process of mushrooms. 
Supplementary Materials: The following are available online at http://www.mdpi.com/2077-0472/10/9/371/s1, Table S1: Statistical results and coefficients of models of mushrooms under different drying conditions.

Author Contributions: Conceptualization, A.F., M.H., and M.N.; methodology, M.H. and M.N.; software, A.F. and M.N.; validation, M.N. and M.H.; formal analysis, A.F., M.H., and M.N.; investigation, A.F.; resources, M.H.; data curation, M.H. and M.N.; writing—original draft preparation, M.N.; writing—review and editing, A.J.S.; visualization, M.H., M.N., and A.J.S.; supervision, M.H.; project administration, M.H. and M.N.; funding acquisition, A.J.S. All authors have read and agreed to the published version of the manuscript.

Funding: This research received no external funding.

Acknowledgments: Authors sincerely thank the Agricultural Sciences and Natural Resources University of Khuzestan for supporting this study.

Conflicts of Interest: The authors declare no competing financial interest.

\section{References}

1. Lin, X.; Xu, J.-L.; Sun, D.-W. Investigation of moisture content uniformity of microwave-vacuum dried mushroom (Agaricus bisporus) by NIR hyperspectral imaging. LWT 2019, 109, 108-117. [CrossRef]

2. Zhang, K.; Pu, Y.-Y.; Sun, D.-W. Recent advances in quality preservation of postharvest mushrooms (Agaricus bisporus): A review. Trends Food Sci. Technol. 2018, 78, 72-82. [CrossRef]

3. Roueita, G.; Hojjati, M.; Noshad, M. Study of physicochemical properties of dried kiwifruits using the natural hypertonic solution in ultrasound-assisted osmotic dehydration as pretreatment. Int. J. Fruit Sci. 2020. [CrossRef]

4. Noshad, M.; Mohebbi, M.; Shahidi, F.; Mortazavi, S.A. Kinetic modeling of rehydration in air-dried quinces pretreated with osmotic dehydration and ultrasonic. J. Food Process. Preserv. 2012, 36, 383-392. [CrossRef]

5. Darvishi, H.; Azadbakht, M.; Noralahi, B. Experimental performance of mushroom fluidized-bed drying: Effect of osmotic pretreatment and air recirculation. Renew. Energy 2018, 120, 201-208. [CrossRef]

6. Pei, F.; Xiao, K.; Chen, L.; Yang, W.; Zhao, L.; Fang, Y.; Ma, N.; Mariga, A.M.; Hu, Q. Mass transfer characteristics during ultrasound-assisted osmotic dehydration of button mushroom (Agaricus bisporus). J. Food Sci. Technol. 2019, 56, 2213-2223. [CrossRef]

7. Salehi, F.; Kashaninejad, M.; Jafarianlari, A. Drying kinetics and characteristics of combined infrared-vacuum drying of button mushroom slices. Heat Mass Transf. 2017, 53, 1751-1759. [CrossRef]

8. Artés, F.; Gómez, P.; Aguayo, E.; Escalona, V.; Artés-Hernández, F. Sustainable sanitation techniques for keeping quality and safety of fresh-cut plant commodities. Postharvest Biol. Technol. 2009, 51, $287-296$. [CrossRef]

9. Ribeiro, C.; Alvarenga, B. Prospects of UV radiation for application in postharvest technology. Emir. J. Food Agric. 2012, 24, 586-597. [CrossRef]

10. Villa-Rodriguez, J.A.; Palafox-Carlos, H.; Yahia, E.M.; Ayala-Zavala, J.F.; Gonzalez-Aguilar, G.A. Maintaining antioxidant potential of fresh fruits and vegetables after harvest. Crit. Rev. Food Sci. Nutr. 2015, 55, 806-822. [CrossRef]

11. Braga, T.R.; Silva, E.O.; Rodrigues, S.; Fernandes, F.A. Drying of mangoes (Mangifera indica L.) applying pulsed UV light as pretreatment. Food Bioprod. Process. 2019, 114, 95-102. [CrossRef]

12. Joshi, D.; Mohandass, C.; Dhale, M. Effect of UV-B radiation and desiccation stress on photoprotective compounds accumulation in marine Leptolyngbya sp. Appl. Biochem. Biotechnol. 2018, 184, 35-47. [CrossRef]

13. Rikabad, M.M.; Pourakbar, L.; Moghaddam, S.S.; Popović-Djordjević, J. Agrobiological, chemical and antioxidant properties of saffron (Crocus sativus L.) exposed to TiO2 nanoparticles and ultraviolet-B stress. Ind. Crops Prod. 2019, 137, 137-143. [CrossRef]

14. Klungboonkrong, V.; Phoungchandang, S.; Lamsal, B. Drying of Orthosiphon aristatus leaves: Mathematical modeling, drying characteristics, and quality aspects. Chem. Eng. Commun. 2018, 205, 1239-1251. [CrossRef]

15. Keneni, Y.; Hvoslef-Eide, A.T.; Marchetti, J. Mathematical modelling of the drying kinetics of Jatropha curcas L. seeds. Ind. Crops Prod. 2019, 132, 12-20. [CrossRef]

16. Zhang, Z.; Liu, Z.; Liu, C.; Li, D.; Jiang, N.; Liu, C. Effects of ultrasound pretreatment on drying kinetics and quality parameters of button mushroom slices. Dry. Technol. 2016, 34, 1791-1800. [CrossRef]

17. Yan, Z.; Sousa-Gallagher, M.J.; Oliveira, F.A. Shrinkage and porosity of banana, pineapple and mango slices during air-drying. J. Food Eng. 2008, 84, 430-440. [CrossRef] 
18. Szadzińska, J.; Łechtańska, J.; Pashminehazar, R.; Kharaghani, A.; Tsotsas, E. Microwave-and ultrasound-assisted convective drying of raspberries: Drying kinetics and microstructural changes. Dry. Technol. 2019, 37, 1-12. [CrossRef]

19. Minolta. Precise Color Communication: Color Control from Feeling Instrumentation; Konica Minolta Co., Ltd.: Osaka, Japan, 1994.

20. CIE. (Commission Internationale de l'Eclairage) Colorimetry-Technical Report; Central Bureau of the CIE: Vienna, Austria, 2004; pp. 16-20.

21. Vallespir, F.; Rodríguez, Ó.; Eim, V.S.; Rosselló, C.; Simal, S. Freezing pre-treatments on the intensification of the drying process of vegetables with different structures. J. Food Eng. 2018, 239, 83-91. [CrossRef]

22. Mahapatra, A.; Tripathy, P.P. Modeling and simulation of moisture transfer during solar drying of carrot slices. J. Food Process Eng. 2018, 41, e12909. [CrossRef]

23. Demiray, E.; Seker, A.; Tulek, Y. Drying kinetics of onion (Allium cepa L.) slices with convective and microwave drying. Heat Mass Transf. 2017, 53, 1817-1827. [CrossRef]

24. Erbay, Z.; Icier, F. A review of thin layer drying of foods: Theory, modeling, and experimental results. Crit. Rev. Food Sci. Nutr. 2010, 50, 441-464. [CrossRef]

25. Anvar, A.; Nasehi, B.; Noshad, M.; Barzegar, H. Drying kinetics and optimization of microwave-assisted drying of quince pomace. Iran. Food Sci. Technol. Res. J. 2017, 12, 750-757.

26. Mahawar, M.K.; Jalgaonkar, K.; Bibwe, B.; Ghodki, B.; Bhushan, B. Mathematical modelling and drying kinetics of kinnow and sweet lime peels. Int. J. Chem. Stud. 2017, 5, 885-888.

27. Ameri, B.; Hanini, S.; Boumahdi, M. Influence of drying methods on the thermodynamic parameters, effective moisture diffusion and drying rate of wastewater sewage sludge. Renew. Energy 2020, 147, 1107-1119. [CrossRef]

28. Nguyen, T.K.; Mondor, M.; Ratti, C. Shrinkage of cellular food during air drying. J. Food Eng. 2018, $230,8-17$. [CrossRef]

29. Adiletta, G.; Russo, P.; Senadeera, W.; Di Matteo, M. Drying characteristics and quality of grape under physical pretreatment. J. Food Eng. 2016, 172, 9-18. [CrossRef]

30. Antal, T. Comparative study of three drying methods: Freeze, hot air-assisted freeze and infrared-assisted freeze modes. Agron. Res. 2015, 13, 863-878.

31. Senadeera, W.; Adiletta, G.; Önal, B.; Di Matteo, M.; Russo, P. Influence of different hot air drying temperatures on drying kinetics, shrinkage, and colour of persimmon slices. Foods 2020, 9, 101. [CrossRef]

32. Arabhosseini, A.; Padhye, S.; Huisman, W.; van Boxtel, A.; Müller, J. Effect of drying on the color of tarragon (Artemisia dracunculus L.) leaves. Food Bioprocess Technol. 2011, 4, 1281-1287. [CrossRef]

33. Sagar, V.; Kumar, P.S. Recent advances in drying and dehydration of fruits and vegetables: A review. J. Food Sci. Technol. 2010, 47, 15-26. [CrossRef] [PubMed]

34. Yu, Y.; Wang, J. Effect of gamma-ray irradiation on drying characteristics of wheat. Biosyst. Eng. 2006, 95, 219-225. [CrossRef]

35. Touil, A.; Chemkhi, S.; Zagrouba, F. Moisture diffusivity and shrinkage of fruit and cladode of Opuntia ficus-indica during infrared drying. J. Food Process. 2014, 2014. [CrossRef]

36. Zielinska, M.; Markowski, M.; Zielinska, D. The effect of freezing on the hot air and microwave vacuum drying kinetics and texture of whole cranberries. Dry. Technol. 2019, 37, 1714-1730. [CrossRef]

(C) 2020 by the authors. Licensee MDPI, Basel, Switzerland. This article is an open access article distributed under the terms and conditions of the Creative Commons Attribution (CC BY) license (http://creativecommons.org/licenses/by/4.0/). 